Tér és Társadalom 20. évf. 2006/3. 19-30. p.

Tér és Társadalom

XX.évf. 2006 3: 19-30

\title{
GAZDASÁGI KAMARÁK A GLOBALIZÁCIÓBAN
}

\author{
(Economic Chambers and Globalisation)
}

\author{
PÓLA PÉTER
}

Kulcsszavak:

globalizáció helyi gazdaság versenyképesség

A tanulmány azt vizsgálja, hogy a globalizáció mikém alakítja àt a helyi gazdasăgi feltételrendszereket. hogyan befolyásolja a helyi vállalkozások helyzetét, versenyképességét, s ebben az állandóan és gyorsan változó társadalmi-gazdasági kömyezelben a kamarák képesek-e olyan stratégiát kialakítani, amely alapján az altaluk képviselt gazdaság szereplöi szímaira eredményes versenvképességi szolgálatot jelenthetnek. A terilleti gazdasági kamarák alapvetö feladata a helvi gazdasảg érdekeinek általános képviselete, a helyi vállalkozások versenyképességénck erösítése, „hetyzetbe hozása”. Mint a helyi, regionális gazdaság érdekeinek szószólói, és mint a helyi gazdaságfejlesztés meghatározó (vagy potenciális) sze replöi, a gazdasági kamaräknak a globalizáció kihívásaira adott válaszai hatással leheetnek a hel yi gazdaság versenyképességének clakulasarar is.

\section{Bevezetés}

A globalizáció folyamata jelentös változásokat idéz eló a helyi gazdaságban és társadalomban. A kis- és középvállalkozások (KKV) gazdálkodási biztonsága jelentösen csökkenhet. A globalizáció a helyi gazdaság és a KKV szektor számára olyan kihívást jelent, amely jórészt még nem is tudatosodott sem a helyi döntéshozókban, sem a kis- és középvállalkozások többségében. A folyamat negatív jelenségeinek kezelése, a helyi, a társadalomba ágyazódott KKV-k versenyképességének fokozása a jelenlegi nemzeti, regionális és lokális intézményrendszerek, köztük a kamarák talán legfontosabb feladata. A globalizációval együtt járó lokalizáció mindeközben felértékeli a helyi fejlesztés koncepcióját, $s$ az alulról építkezö, önigazgatás elvén múködő szervezeteket hozhatja helyzetbe. E tekintetben a gazdasági önkormányzatok szerepe egy térség fejlesztésében egyre fontosabb lehet. Szerepük akkor lehet igazán hatékony és eredményes, ha a változó viszonyokhoz igazítják stratégiájukat, s persze akkor, ha erre a kivívásra nemcsak készek és szakmailag kompetensek, de megfelelö felhatalmazással és eröforrásokkal rendelkeznek.

\section{A kamarák a gazdaságszervezés, -fejlesztés intézményrendszerében}

A gazdaságszervezés a piacgazdaságban alapvetően három szintet foglal magában (Farkas 2000):

- állami szféra: állami, kormányzati szervezetek (meghatározott törvényhozó, végrehajtó és ellenőrző tevékenységekkel),

- mikroszféra: a vállalkozói-üzleti világ egésze, 
- köztes szféra: az előző kettő között, a gazdaságszervezési „szendvics” közepén elhelyezkedő szféra a maga sajátos intézményeivel, szervezeteivel és tevékenységével.

A köztes szféra szervezetei, intézményei az állami és/vagy mikroszint által meghatározott közegben és általuk meghatározott feladatok ellátására jönnek létre és múködnek. A gazdasági kamarákat is e köztes szféra szereplöi közé lehet sorolni más gazdasági érdekképviseletek és szakmai szervezetek, gazdaságfejlesztéssel foglalkozó szervezetek közé. E szféra szereplöi, bekapcsolódva a gazdaságszervezés, az önigazgatás folyamataiba, mindkét szféra kiszolgálásában részt vesznek (Farkas 1997). A piacgazdaság megfeleló müködéséhez elengedhetetlen, hogy létezzenek és hatékonyan müködjenek a köztes szféra intézményei.

A társadalomba beágyazott intézmények szerepétől nem független a vállalatok müködése sem. A siker egyik feltétele, hogy a vállalat ismerje és alkalmazza azokat a kapcsolatokat, amelyek saját környezetében fellelhetök (Andrási 1997). Nemcsak hasznos szakmai információk áramlanak a szervezetek és vállalatok között, és különféle szolgáltatásokkal segíthetik a vállalkozásokat, de talán az egyik legfontosabb szerepük abban van, hogy hálózataikon keresztül ,élö kapcsolatot jelentenek az abban részt vevö vállalkozásoknak más nemzetközi szervezetek, piacok felé" (Andrási 1997, 4).

Az alábbi I. ábra mutatja be, hogy egy tipikus vállalkozói önkormányzat (gazdasági kamara) milyen fö kapcsolódásokkal és tevékenységgel vesz részt a gazdaságszervezés folyamatában.

\section{1. ÁBRA}

A kamarák jellemzö viszonyai és tevékenysége a gazdaságszervezésben (Affect and Activity of Chambers in Organising Economy)

\begin{tabular}{|c|c|c|}
\hline $\begin{array}{c}\text { Tevékenység } \\
\text { iránya }\end{array}$ & Tevékenység tartalma & Tevékenység helye \\
\hline \multirow[t]{2}{*}{$\begin{array}{c}\text { KAMARÁN } \\
\text { KÍVÜLI } \\
\text { (MAKROSZFÉRA) }\end{array}$} & $\begin{array}{l}\text { Alkalmazkodás: a hatalomhoz, a politikai } \\
\text { rendszerhez, a kormányzathoz, különös } \\
\text { tekintettel a gazdaságirányítás, gazdaság- } \\
\text { politika, gazdaságszervezés terén }\end{array}$ & \\
\hline & $\begin{array}{l}\text { Érdekképviselet, érdekérvényesítés: a } \\
2 \text { (tag)vállalkozói szféra érdekeinek meg- } \\
\text { ismerése és megjelenítése }\end{array}$ & $\begin{array}{l}\text { KAMARÁN BELÜL } \\
\text { KATALIZÁLANDÓ }\end{array}$ \\
\hline $\begin{array}{c}\text { KAMARÁN } \\
\text { KÍVÜLI } \\
\text { (MIKROSZFÉRA) }\end{array}$ & $\begin{array}{l}\text { Szolgáltatások: fenntartás, kiszolgálás, } \\
\text { folyó müködést elösegítő tevékenységek, } \\
\text { különösen „,business development”, ezen } \\
\text { belül elsősorban: } \\
\text { vállalkozásfejlesztés (egyedi, egyes } \\
3 \text { vállalkozásokkal foglalkozik) } \\
\text { gazdaságfejlesztés (makro- } \\
\text { „mezoszintü”, illetve kollektív } \\
\text { egyéb speciális fejlesztö tevékenységek } \\
\text { (pl. innováció, kereskedelemfejlesztés, } \\
\text { területfejlesztés) }\end{array}$ & \\
\hline
\end{tabular}

Forrás: Farkas (2000) 15. o. 


\section{A kamarák jogállása, kamarai modellek}

A magyar kamarai törvény értelmében a kamarák köztestületi önkormányzatok. A kamaráknak a törvény felhatalmazásánál fogva egyrészt a gazdaság általános érdekeinek érvényesítését kell megoldaniuk, másrészt a feladataikat nem csupán tagjaik, hanem a teljes gazdaság vonatkozásában el kell látniuk. Ez a kamarák köztestületiségének lényege, ez különbözteti meg őket az érdekképviseleti és más szervezetektöl.

Köztestületeket az állam rendszerint olyan feladatok betöltésére létesít, illetve ismer el, amelyek ellátására saját bürokratikus szerveivel nem vállalkozik, viszont amelyeket a közvetlen érintettek önkormányzati szervezetükben eredményesen meg tudnak oldani. Bár Illés (2001) felhívja a figyelmet arra, hogy a döntés lejjebb vitele veszélyeket is rejt magában, több érv szól amellett, hogy a döntéseknek a döntés hatásterületéhez közelebb vitele számos elönnyel jár. Ilyen előny például, hogy a döntéshozók jobban ismerik a helyi viszonyokat; hogy a lokális erőforrások feltárása és hasznosítása könynyebb, a különbözỏ ágazatokba tartozó helyi gazdasági szervezetek érdekei és együttmüködése jobban szervezhetö, érdekeik jobban összehangolhatók (Illés 2001). A köztestuiletek tehát a döntéshozók megfeleló tájékozottsága, szakmai felkészültsége és az igazgatás eredményességében való érdekeltség folytán meghatározott közigazgatási ügyekben hatékonyabban láthatnak el kỏzigazgatási feladatokat, mint az állami vagy a helyi önkormányzati szervek. Ez pedig a gazdaságfejlesztéssel, gazdaságszervezéssel kapcsolatos (köz)feladatok ellátása szempontjából nem mellékes.

\section{Magánjogi és közjogi kamarák}

A piacgazdaságokban, alapvetỏen kétféle kamarai irányzat létezik. Az egyik a magánjogi kamara, gyakran nevezik angolszász vagy plurális modellnek is (legtisztábban az USA-ban jelenik meg, lényegében lobby szervezet, közfeladatok nélkül). A magánjogi rendszer tíz európai országban terjedt el. Tipikus példái a brit kamarák, de magánjogi kamarák müködnek a skandináv országokban, Írországban, Belgiumban, Svájcban és Portugáliában is. E kamarák az egyesülési törvény hatálya alá tartoznak, szabadon állapíthatják meg szervezeti felépítésuiket, elsősorban érdekképviseleti feladatokat teljesítenek. Erös versenyhelyzetben múkỏdnek, ami állandó nyomást jelent a szolgáltatások színvonalának emelésére. Problémát a korlátozott taglétszám, s ebböl is fakadóan a kamarák változó minösége és kompetenciája okoz, ami korlátozza a kamaráknak a központi vagy regionális döntéshozatal összefogott befolyásolását segító képességét (Számely 1996; Kiss 1994). Szintén problémát jelent a szabályozatlan területi lefedettség is, valamint az, hogy a magánjogi kamarák az önkéntes tagságtól függnek, alapvetỏen csak saját szolgáltatásaik bevételére és a tagdíjakra számíthatnak 
A közjogi kamara (kontinentális vagy korporatív modell) szervezetileg intézményként értelmezhetô. Ez a köztestületi szabályozású, érdekkiegyenlitést szolgáló, automatikus tagságú kamara terjedt el a legtöbb európai országban, alapvetően neokorporatív ${ }^{\prime}$ jellegü szabályozás jellemzi. A köztestületi szabályozáson alapuló kamarák a szakmai szempontok érvényesülését hivatottak elősegíteni az érdekeltek, a helyi vállalkozások döntéseire alapozva. Számos szolgáltatást nyújtanak zömmel a KKV szektor számára, melyet köztestületi státuszuk és az automatikus tagság révén elégséges anyagi eszközök tesznek lehetövé. A gazdaság képviseletére, az országos és a helyi gazdasági döntések befolyásolására törvény által biztosított joguk van. Szervezeti rendjüket ennyiben kíviilállók is meghalározzák, ugyanakkor tételesen lefekteıtt rendje, belsö szabályzata van. és vezetôjét șem kivülállók nevezik ki (Fehérvári 2000). Bizonyos hatósági feladatokkal is rendelkeznek, hatáskörük országonként eltérő. Ez a korrọoratív vonulat erőscon beépül az adott társadalom felépítményébe, számos területen teljes mértér:ben átveszi à állam szerepét. A szakképzés, kereskedelemfejle`ıtés mell'ıt a ga:izdasigi infrastruktúra müködtetése is egyre gyakrabban a kanarák kezébe kerül.

\section{A magyar kamarai szabályozás}

Az 1994-es magyarországi kamarai törvény a közjogi, azon belül is alapvetöen $a$ német modellt vette alapul, de az 1994. évi XVI törvény a tradíciókhoz nyúlt vissza, amikor a kötelező tagságon alapuló közjogi kamarai modellt vezette be. Néhány évvel később, 1999-ben azonban új törvény született, melynek értelmében a kamarának továbbra is minden vállalkozás felé szolgáltatási kötelezettsége áll fenn, el kell látnia az egész gazdaság érdekvédelmét, de e munkájában csak az önkéntes tagok tagdíjára számíthat. Bár a kanıarák köztestületi jellege megmaradit, az automatikus tagságot az új jogszabály eltörölte, a hatályos törvény értelmében a tagság önkéntes. Mindez olyan feszültségeket, múködés-finanszírozási problémákat okoz, ami a kamarák hatékony múködését nehezíti.

A hazai kamarákat többek között az alábbi közfeladatokkal ruházta fel a törvény²:

- a gazdaságfejlesztési, vállalkozásfejlesztési, gazdaság stratégiai döntések elókészítésében való részvétel;

- iparjogvédelem;

- kis- és középvállalkozásc! integrációs felkészítése;

- gazdasági, mủszaki, környezetvédelmi, jogi információk gyüjtése és rendelkezésre bocsátása;

- szakképzéssel összefüggő feladatok (pl. mesterképzés, mestervizsgáztatás, gazdálkodó szervezetek gyakorlati képzőhelyeinek ellenörzése, minősítése) stb. 


\section{A gazdasági kamarák jövője a globalizálódó gazdaságban}

A globalizáció elemzése során e tanulmány arra keres választ, hogy a helyi, regionális gazdaságok és azok lokális intézményrendszere miként tud beilleszkedni a nemzetközi rendszerbe. Nem pusztán a nemzetközi gazdasági folyamatokba, hanem egy strukturált (és hierarchikus) rendszerbe (Andor 2003), hiszen ma már lényegében valamennyi ország gazdasága egy funkcionálisan összekapcsolódó globális rendszer részét alkotja. Végtelen pólusú világ alakul ki (Kiss E. 1999), amelyben az egyes aktorok lehetőségei elvileg óriásiak, hiszen bármely kisvállalkozás terméke a multinacionális kereskedelmi láncok által megjelenhet szinte a világ bármely pontján. Vagyis miközben a legfelső szinten a világ egységesül, addig a legalsó szinteken az egyediség, a lokalitások mindenütt a világon megismerhetőek (Gazdag 2000; Varga 2000). Ezek a változások sajátos gazdasági, társadalmi, politikai követelményeket, elvárásokat indukálnak.

Ma a gazdaságfejlődés irányait, hajtótényezőit, sajátos vonásait a globalizációlokalizáció kettős folyamata jellemzi. „A piac globalizálódása és ezzel párhuzamosan a gazdasági tevékenységek lokalizációjának felértékelódése által meghatározott gazdaság- és piacfejlödési irányzat megerösítette a terủleti gazdaságfejlesztési és szervezési funkciót, a megvalósítás eszköztárát sokszínủbbé tette, új fejlesztésiszabályozási súlypontok jöttek létre. Ennek hátterében a gazdaság és az adott térség (közösség) egyre erősödó közvetlen anyagi érdekközössége áll." (Hrubi 2004, 162) A globalizáció egészének tehát természetes velejárója a lokalitások felértékelödése, ennek megfelelően a helyi gazdaság fejlesztése mindinkább központi kérdése lesz a hazai regionális és gazdaságpolitikai stratégiáknak is (Mezei 2003).

A nemzetközi versenyképesség előfeltétele a helyi versenyképesség, amelyet újra és újra elö kell állítani. Mivel a verseny globális, az eredményesség mércéit a világgazdaság definiálja, de a szereplöknek nem lehet kivonni magukat a helyi feltételekből, ezért a helyi társadalmat kell alkalmassá tenni versenyképességük fenntartásával, növelésével (Szigeti 2003). Enyedi (2000) a versenyképességet befolyásoló helyi adottságok közé sorolja a tágabb értelmü intézményi környezetet is.

Egy vállalat és versenytársai termékeinek minősége egyre kiegyenlítettebb, a vállalatok stratégiája ezért: erős hálózatokba szerveződés, melyek keretében képesek kihasználni a méretgazdaságosság elönyeit. Azoknak a vállalatoknak van esélye a talpon maradásra, amelyek vagy teljesen speciális termékeket tudnak elöállítani vagy azoknak, amelyek az anyagbeszerzéstől a termelésen át az értékesítésig hálózatot hoznak létre.

A nyolcvanas évektől a fejlett országok vállalati és iparági esettanulmányai azt mutatják, hogy a cégek sikeressége és versenyképessége egyre inkább lokális üzleti környezetük minőségétől függ. A globális versenyben egy adott iparághoz tartozó cégek és üzleti partnereik, a kapcsolódó helyi intézmények, azaz a hálózatok és a klaszterek jelentősége felértékelödött, amelyek a térbeli koncentrálódásából eredő lokális előnyöket használják ki (Grosz 2005). A klaszterek, hálózatok előbb-utóbb piaci alapon önmaguktól is létrejönnek, de fejlesztési támogatásokkal, a piaci 
aktoroktól a szervezés-menedzselés feladatát idölegesen átvállalva gyorsítható a folyamat (Hrubi 2002). Ezeknek a hálózatoknak az alakításában a hazai gazdasági kamaráknak is katalizátor szerepe lehet, amennyiben tagjaik között tudják mind a kisvállalkozások, mind a multinacionális vállalatok jelentős részét ${ }^{3}$.

A vállalkozások - úgy a kis- és középvállal kozások, mint a multinacionális cégek - társadalmi beágyazottsága fontos elemzési szempont. A különbözö térségek egymással kerülnek versenyhelyzetbe, és az „,egyre markánsabbá váló területi gazdasági érdek érvényesítéséhez tartós partnerségre van szükségük" (Hrubi 2002, 31). Kutatásaim azt igazolják, hogy ennek a partnerségnek a kialakításában, menedzselésében a kamarák igyekeznek szerepet vállalni.

Miközben a nemzetközi vállalat nemzetközi szinten optimalizál, a helyi kisvállalkozások egy jelentős része - amíg teheti - kötödik székhelyéhez. A hazai szakirodalom szerint a helyi gazdaság fejlódése számára nagyon fontos a külföldi vállalatok lokális beágyazottsága is (Szirmai-Baráth-Molnár-Szépvölgyi 2003). Ennek révén nemcsak jobban integrálódik a tőke (Barta 2002), de lényeges azért is, mert, „a globális és lokális folyamatok, a folyamatokat reprezentáló gazdasági és társadalmi erők viszonya hosszú távon meghatározzák a globalizáció jellegzetességeit, konkrét hatásmechanizmusait és a lokális érdekek érvényesülését" (SzirmaiBaráth-Molnár-Szépvölgyi 2003, 34). Eközben a multinacionális vállalatok szigetszerü létezésére utal, hogy e cégek többnyire külföldi beszállítói kapcsolatokat tartanak fent, termékeiket fỏként exportálják (Szalcii 2001). Az Európai Unió tagországainak gazdaságában általában 30-50\%-ot tesz ki a beszállítói kör, míg Magyarországon az egyes multinacionális vállalatok által foglalkoztatott beszállítók aránya alig haladja meg a 10\%-ot (Szirmai-A. Gergely-Baráth-Molnár-Szépvölgyi 2002).

A vállalkozások társadalmi beágyazottságának kérdése a gazdasági kamarák szempontjából is fontos, hiszen a kamara tradicionális erejét, aktív tagjait a helyi társadalomba beágyazott vállalkozások jelentik. Azok az üzletemberek, akik túl személyes érdekeiken - de nem annak ellenében - a helyi társadalom, a köz érdekeiért is tevékenykednek azt vallják, hogy a helyi üzleti közösséghez tartozni azért is érdemes, mert olyan bizalmi háló is kiépül általa, amely bár nem forintosítható, de nagyon fontos érték egy vállalkozás számára. Ezek a típusú kötődések ugyanakkor éppen a globalizáció erösödésével gyengülnek, veszítenek jelentöségükböl. Egyre kevésbé van jelen társadalomban és a helyi vállalkozásokban az a hagyományos értékrendszer, amelynek alapja a környezetemért, városomért, a helyi társadalomért érzett felelösség. Különösen nem jellemzö ez a multinacionális vállalati körre. Jól jellemzi a mai körülményeket Veress (2004), aki úgy fogalmaz, hogy bár a nagybefektetök számára komoly körültekintést igényel az eltérő szabályozások megismerése, stratégiáik ezekhez igazítása, ugyanakkor a lehetőségek ismeretében gyors döntéseket képesek hozni a tőkeberuházásokat illetően, melynek során „egyáltalán nem kell számolniuk a döntések szűkebb és tágabb értelemben vett társadalmi, szociális következményeivel" (Veress 2004, 36). Nem véletlen, hogy a Magyar Kereskedelmi és Iparkamara stratégiai programjában támogatja azt az EU-irányelvet, amely a vállalatok társadalmi felelősségének előmozdításáról szól. 


\section{A kamarák nemzetközi hálózatai}

A globalizációs folyamat negatív jelenségeinek kezelése, a helyi társadalomba ágyazódott kis- és középvállalkozások versenyképességének fokozása a jelenlegi nemzeti, regionális és lokális intézményrendszerek talán legfontosabb feladata.

A kamarák európai szövetsége, a Eurochambres ezeket a kihívásokat felismerve hirdette meg a több mint 15000 tagkamara hálózattá fejlesztését, a szolgáltatások standardizálását. A Eurochambres lehetőségei a nemzeti és helyi kamarák elvárásaival szemben azonban legfeljebb az európai integrációs szintủ versenyképesség erösítésére korlátozódnak. A kamarák többsége ezért számos más együttmüködési szervezetben igyekszik a globalizációs kihívásokat kezelni. Vagyis a nemzetköziesedés ellen maga is nemzetközi folyamatokat indít be. A világ legnagyobb üzleti szövetsége az ICC (Nemzetközi Kereskedelmi Kamara) szerepe is dinamikusan nö, a világszintü koordináció mellett egyre aktívabbak a nemzeti bizottságok, jelentős szerepet vállalnak a nemzetközi kereskedelem és gazdasági együttmüködés jogi, kereskedelemtechnikai hátterének megteremtésében, propagálásában. Persze ezen a szinten inkább a nemzetközi vállalatok aktivizálódnak, így maga az ICC eleve alkalmatlan a globalizáció bármilyen ellensúlyozására a nemzeti KKV-k irányába (Kerényi 2004), sốt bizonyos értelemben a globalizáció egyik hordozójává vált. A kamarák, mint látjuk, arra törekszenek, hogy maguk is nemzetközi hálózatokba szervezödve - globalzációs eszközökkel - hatékonyabban segítsék a helyi gazdaság versenyképességét. Egy-egy szűkebb közösség (város, régió, ország) jövöje múlhat azon, hogy a helyi vállalkozásokat ebben a közegben sikerül-e versenyképessé tenni (Síkföi 2006).

\section{A területi gazdasági kamarák stratégiái}

A gazdasági kamaráknak a stratégiájuk kialakítása során a globalizáció helyi gazdaságra ható tényezőit nem hagyhatják figyelmen kívül. A helyi vállalkozások és a kamarák számára is alapvető fontosságú az a felismerés, hogy ha nincs lokális együttmúködés, akkor nincs globális verseny. A jól ismert „Gondolkodj globálisan, cselekedj lokálisan!" elvet kell szem elött tartani akkor, amikor a kamarák és a bázisukat képezó vállalkozások a globalizáció kihívásaival találkoznak. A kamarák legfontosabb törekvése, a helyi kis- és középvállalkozások versenyképességének javítása csak úgy valósítható meg, ha ezek a cégek bekapcsolódnak a globalizáció rendszerébe.

A kamarai intézmény hosszú távú eredményes múködése szempontjából meghatározó a versenyképességi tényezők közé sorolható intézményrendszer hatékonyságának kérdése, vagyis a szervezeti modernizáció. A modern társadalom és gazdaság középpontjában nem csak a technológia, az információ és a termelékenység áll, de az eredmények elérésére képes szervezett intézmény is (Kéri 2006). Olyan intézményrendszerre van szükség, amelyben a regionális szervezetek elsődleges feladata, hogy a helyi eröforrásokat hasznosító, helyi igényeket kielégítő, helyi termelöket segítsék abban, hogy versenyképességükkel meg tudják örizni piacaikat, eröforrásaikat. 
A területi kamaráknak pontosan kell ismerni a vállalkozások kamarával kapcsolatos elvárásait, tevékenységüket ezekhez kell igazítani. A különbözö vállalkozástípusok kamarai szolgáltatások iránti kereslete eltérő. A kisvállalkozások egészen más jellegủ segítséget várnak a kamaráktól, mint a nagyvállalatok, amelyek alapvetően az alábbi kamarai szolgáltatásokat igénylik:

- gazdasági folyamatok követése, elemzése;

- állami és helyi szabályozások, stratégiai törekvések nyomon követése;

- helyi és országos politikai viszonyokkal kapcsolatos, elemzések információk;

- helyi kapcsolatépítés;

- munkaerö-piac stb.

A kis- és középvállalkozások heterogén bázisát jelentik a kamaráknak, jellemzően három csoportra oszthatók. Az egyik csoportba a tőkeerős, fejlesztésekre is képes, többnyire a nagy beszállítói rendszerekhez kapcsolódó, közepes méretủ vállalkozások tartoznak. Számukra a kamara müszaki fejlesztési, kereskedelemfejlesztési szolgáltatásai és kapcsolatépítő tevékenysége fontos. A másik jellemző csoportot a generációs középvállalkozások alkotják. Ők lényegében „öröklik” a kamarai tagságot, szocializációjuk okán is szükséges mozgásformának tekintik a kamarát. A harmadik csoportba a többnyire új alapítású kis- és középvállalkozások tartoznak. A tipikus és racionális „Mit kaphatok a kamarától?" kérdést ugyanakkor nem csak anyagi és szakmai alapon mérlegelik. A kamarához való pozitív viszonyulásukban fontos helyen van, hogy a kamarán keresztül kapcsolódhatnak a helyi üzleti közösséghez. A vállalkozás így része lesz az információáramlásnak, új kapcsolatrendszereket alakíthat ki, ami később új üzletekben is megtestesülhet. Vagyis az ő érdekükben kifejtett jellegzetes kamarai tevékenység a közösség- és a kapcsolatépítés. Utóbbi jelentheti az egyetemekkel, $\mathrm{K}+\mathrm{F}$ helyekkel való kapcsolatok létesítését, illetve azt az egyre jellemzőbb kamarai szerepvállalást, ami ezeknek a vállalkozásoknak kereskedelmi rendszerekbe (szakvásárok, üzletember találkozók szervezése), innovációs láncokba, klaszterekbe szervezését próbálja meg segíteni.

Palkovits (2000) egy tanulmányában a lokális gazdaság adottságait dinamikus elemekkel ötvöző gazdaságfejlesztési stratégia fontosabb elemeit foglalta össze. melyek az alábbiak:

- „hely-kompatibilis” vállalatok, iparágak azonosítása és vonzása,

- helyi vállalatok alapításának és expanziójának támogatása,

- infrastruktúra-fejlesztéssel kapcsolatos feladatok,

- képzett munkaerőbázis kialakítása,

- erős közösségi - magán partnerség megteremtése,

- szolgáltatás-barát környezet kialakítása,

- megkülönböztetett helyi attrakciók létrehozása,

- végül mindezen elönyök hatékony promóciója. 
Észrevehető, hogy ezek az elemek a legtöbb nyugat-európai kamara aktivitási területeinek felelnek meg, $\mathrm{s}$ a hazai kamarai szerepvállalások is egyre inkább ezeknek az elemeknek a hangsúlyozására, létrehozására, fejlesztésére irányulnak.

A területi kamarák legfontosabb törekvése helyi programok alapján a középvállalati szféra megerösítése, a helyi kis- és középvállalkozások versenyképességének javítása. Ehhez kapcsolódó optimális (a globalizáció trendjeit számításba vevő, a tipikus vállal kozói igényeket ismerö) stratégia föbb elemei az alábbiak lehetnek:

- A térség érdekében a nagy autonómiák (helyi önkormányzatok, gazdasági önkormányzatok, egyetemek) egyiittmüködésének ösztönzése, helyi gazdaságfejlesztési stratégiák kidolgozása, kapcsolatépítés, partnerség szervezés: beszállítói programok, regionális klaszterek, tőkevonzási térségi programok kialakítása, koordinálása.

- Hálózatosodás erősítése a magyarországi területi kamarák között és nemzetközi szinten egyaránt. A hazai területi kamarák már ma is jól müködő rendszereket vesznek át egymástól.

- Közösségképzö funkció erösitése, vagyis a helyi vállalkozások minél nagyobb arányának bekapcsolása a helyi üzleti közösségbe, azon keresztül az információáramlásba. Ez aktív kamarai munkával, a vállalkozókkal való személyes kapcsolatfelvétellel és kapcsolattartással elérhető. Az egyes vállalkozóknak és a helyi üzleti közösségnek egyaránt érdeke ez, az elöbbi lehetőségekhez jut, az utóbbi tovább erősödik általa.

- Az információk rendszerezése, feldolgozása, strukturált és jól használható módon átadása a vállalkozások számára. Ha egy vállalkozás információhoz szeretne jutni, alapvetően két lehetősége van: a nagyobb vállalatokra jellemző önálló vállalati információs részleg fenntartása, míg a kisebb vállalkozásoknál az outsourcing, azaz a külső forrásokból történő informálódás a jellemző. A nagyvállalatok információellátása általában problémamentes, hiszen biztos anyagi háttérrel saját apparátusuk végzi el ezeket a feladatokat. A kisvállalkozások tekintetében ugyanakkor vállalaton kívül álló intézményekre van szükség az üzleti típusú informálódáshoz (Kiszl 2005). A cégvezetök a rövid távú gondjaikkal vannak elfoglalva, és kevés időt szánnak információgyűjtésre. Ugyanakkor fontos lenne, hogy 5-10 évre próbáljanak elöre látni, hogy kiszámíthatóvá tegyék a mögöttük álló cég jövőjét. A kamara olyan bázis kell hogy legyen, ahova bármikor bemehetnek, és ott információt és kitekintést kaphatnak (Szücs 2006).

- Vállalkozói érdekek, igények közvetitése a döntéshozók felé, a tipikus álláspontok és vélemények megjelenítése.

- Speciális szolgáltatások nyújtása a tagság körében felmért igényekre alapozva.

- Nem utolsó sorban pedig a lobbizás a kamara által képviselt térség gazdaságának fejlesztése érdekében. 
A hazai gazdasági önkormányzatok megerösödéséhez pedig az alábbiakat tartjuk a legfontosabbnak:

- érdemi, minőségi szolgáltatások nyújtására képes, kreatív, kezdeményező, magas szakmai színvonalú apparátus, amely garantálhatja a szakmai fejlödést, a tökéletesedést a kamarai tevékenységek széles portfoliỏján, vagyis: a szakképzés, az innováció, a kereskedelemfejlesztés, a területfejlesztés, a piacelemzés stb. területén. A szolgáltatások bövítése, színvonalának javítása, fejlödés az információk gyüjtése és rendszerezése terén. Mindehhez a technikai háttér további fejlesztése szükséges.

- A gazdasági önkormányzatokat a gazdaságfejlesztés hatékony eszközeként kezelö, támogató politikai környezet, amelyben a gazdasági kamarák közfeladatai bövülhetnek.

- Nem utolsó sorban pedig erós vállalkozói támogatottság, hiszen a kamarák szintjén ma még relative gyenge az alulról szerveződés, jelenleg a kamara még a vállalkozói oldalon sincs jelen a közgondolkodásban. Ehhez szemléletváltozásra is szükség van, arra, hogy a hazai vállalkozók többsége evidenciaként kezelje azt, ami a legtöbb európai vállalkozó számára régóta az, nevezetesen, hogy: nem a kamarának vannak tagjai, hanem a vállalkozóknak van kamarájuk.

\section{Befejezés}

A versenyképesség nemcsak gazdasági, hanem társadalmi és közigazgatási kategória is. A globalizáció jelentôs megpróbáltatásokat ró a vállalkozásokra, és a mindenkori elvárásoknak csak az tud megfelelni, aki folyamatosan „,képben van”. Ahhoz pedig, hogy képben legyen, egy erős, jól szervezett kamara sokat tehet hozzá. Nem lényegtelen, hogy a kamara, illetve az általa reprezentált szféra tudja megjeleníteni véleményét a gazdaságfejlesztés területén, tudjon információt szerezni, tudja tagjait mozgósítani, tudjon olyan eszközökhöz hozzájutni, amelyek segítségével az adott régió gazdasága dinamizálható.

A globalizáció új területi és versenydimenziói a nemzetközi kapcsolatokban hangsúlyossá teszik a gyorsaság, a kiterjedt térbeli és időbeli dimenzióban való tájékozódás és mozgásképesség fontosságát, amelyek biztosításának egyik fontos csatornája a kamarák kapcsolatrendszere. Ebben a folyamatban a tudatos vállalkozástámogatási politika, a vállalkozások ,helyzetbe hozása” különösen fontos. A gazdasági kamarák lehetőségeit tovább erôsíti az is, hogy a dereguláció, az olcsóbb államok iránti törekvés az önigazgatás bizonyos szervezeti-intézményes formáinak elötérbe kerülését jelenti ( Farkas 2000).

A kamarák jövöje, társadalmi, gazdasági pozíciója nem csupán a törvényi korlátozásoktól vagy elönyöktöl függ, hanem a versenyképességi kihívásokra adandó válaszoktól. A globalizáció és a lokalizáció rajzolta trend versenyképességi rendje a müködési környezetben széles tevékenységi körü gazdaságmenedzselő szervezeteket igényel területi gazdasági szolgáltatási háttérül, ami a piacgazdaság fokozatos 
fejlödésével szükségképpen kialakul, jóllehet, nem feltétlenül piaci alapon álló intézményekrő̂l lehet csak szó (Hrubi 2002). Véleményem szerint ezek az intézmények lehetnek akár maguk a gazdasági kamarák is, ha azonban erre más szervezet létesül vagy kap felhatalmazást, úgy a kamarák aktív együttmüködése indokolható.

A kis- és középvállalkozásoknak egyfajta versenyképességi szolgálatra van szükségük. Ezt a szolgálatot nem csak a kamara láthatja el. Azokat a feladatokat, amelyeket ma a kamarák ellátnak, bizonyára más szervezetek, intézmények is képesek hatékonyan megoldani. A kamarák e tekintetben tehát nem pótolhatatlan intézmények. Mégis úgy gondolom, hogy a gazdasággal kapcsolatos feladatok, funkciók tekintetében olyan komplexitás jellemzi a kamarai intézményrendszert, ami a meglévő funkciók közötti szinergiák miatt jelentős energiák mozgósítására teszi alkalmassá.

Mindezeket figyelembe véve lenne célszerü - az állami bürokrácia karcsúsításával egyidejúleg - a kamarai funkciókat jogszabályi szinten is erősíteni. Így a kamarai rendszerben rejlő energiák is mozgósíthatók.

\section{Jegyzetek}

1 A korporatizmus kifejezést történelmi okok, rossz emlékek miatt a mai demokráciák a neokorporatizmussal helyettesítik, ugyanis a korporatizmus a fasiszta diktatúrák módszere volt a szakszervezetek önállóságának korlátozására. A neokorporatizmus kifejezés azért terjedı el, hogy ez a modell is összeegyeztethetö legyen a demokráciával.

2

A kamarákról szóló, 2003-ban módosított, 1999. évi CXXI. törvény 9-11.\$-ai tételesen sorolják fel a kamarák által ellátandó közfeladatokat, melyekkel a disszertáció késöbbi fejezeteiben többször foglalkozom. Elöljáróban csak annyit jegyzek meg, hogy a kamarai közfeladatok száma a különbözó országok kamarai szabályozásában eltéró és idöben is változhat, ahogy 1994 óta Magyarországon is hol bövült, hol szükült ezeknek a köre.

${ }^{3}$ Meg kell jegyezni, hogy a nemzetközi monopóliumok gyakorta kamara ellenesek, hiszen a kamarák minden országban elsôsorban a nemzeti tỏke képviseletét látják el. A nagy nemzetközi cégek az európai bíróságon is kezdeményezték a kötelező tagság eltö̀lését, de nem jártak sikerrel. Optimális esetben azonban a kamara keretei között gyorsulhat fel az alz információáramlás és kapcsolatépítési folyamat, amelynek eredménye területi és/vagy ágazati klaszterek kialakulása lehet.

\section{Irodalom}

1999. évi CXXI. törvény a gazdasági kamarákról.

Andor L. (2003) Polgári és újbaloldali nézetek a globalizációról. - Lenkei G. (szerk.) Globalizáció. Európai Unió, Gazdaságpolitika. Stratégichi Fï̌etek 13. MeH Stratégiai Elemzö Központ, Budapest. 15-49. 0 .

Andrási Z. (1997) Szakmai szervezetek szerepe a gazdaságban. - Kamarák az ezredfordulón. Gazdaság, vállalkozás, vezetés. $8-9$.

Barta Gy. (2002) A magyar ipar területi folyamatai 1945-2000. Dialóg-Campus Kiádó, Budapest-Pécs.

Enyedi Gy. (2000) Globalizáció és a magyar teruleti fejlödés. Tér és Társadalom. 1. 1-10. o.

Farkas Gy. (1997) Kamarák és vállalati érdekképviseletek szerepe a magyar EU-integrációban. Európai Tïkör. Mühelytanulmányok 27. Integrációs Stratégiai Munkacsoport.

Farkas Gy. (2000) Kamarák és vállalkozói érdekképviseletek az integrációs felkészülésben. Osiris Kiadó, Budapest.

Fehérvári A. (2000) Gazdasági kamarák szerepe a szakképzésben. Doktori értekezés. ELTE TTK, Budapest. Gazdag L. (2000) Globalizáció, korszakvâltás és hazánk esélyei. Gazdiaság és Társadalom. 3-4. 156-187. o.

Grosz A. (2005) Klaszteresedés és klaszterorientált politika Magyarországon - potenciális autóipari klaszter az észak-dunántúli térségben. Doktori értekezés. PTE KTK, Regionális Politika és Gazdaságtan Doktori Iskola. Pécs. 
Hrubi L. (2002) Globalizáció és regionalizáció a gazdaságban - új regionális fejlesztési követelmények. - Kassay J. (szerk.) A kulturális térségek szerepe a regionális fejlesztésben. Válogatás a II. Székelyföld Konferencia elöadásaiból. Székelyföld 2000 Munkacsoport, Csíkszereda. 31-48. o.

Hrubi L. (2004) A megyék gazdaságfejlesztési szerepe. - Pálné Kovács I. (szerk.) Versenyképesség és igazgatás (tanulmányok a regionális versenyképesség iguzgatási feltételeiröl) MTA RKK, Pécs. I6I-180. o.

Illés I. (2001) Régiók és regionalizáció. Tér és Társadalom 1. 1-23. o.

Kerényi J. (2004) A gazdasági kamarák szerepe a helyi gazdaság fejlesztésében. Szakdolgozat. PTE FEEFI, Pécs.

Kéri I. (2006) Kamarai kaleidoszkóp. Dél-Dunántúli Gazzlaság 1. 4-8. o.

Kiss A. (I994) A kereskedelmi és iparkamarák (gazdasági kamarák) szerepe a nemzetközi gazdasági kapcsolatok fejlesztése terén Magyarországon (külföldi kitekintéssel). Doktori értekezés. BKE, Budapest.

Kiss E. (1999) A globalizáció társadalomfilozófiájához. InCo - internetes folyóirat. elérhetöség: www.inco.hu/incol/global/cikkl

Kiszl P. (2005) Üzleti információ, céginformáció és a könyvtárak. ELTE, Traduirex, Budapest. 235. o.

Mezei C. (2003) A helyi gazdaságfejlesztés nemzetközi gyakorlata. - Mezei C. (szerk.) Évkönyv 2002. Pécsi Tudományegyetem Kơzgazdaságtudományi Kara Regionális Politika és Gazdaságtan Doktori Iskola, Pécs.

Palkovits 1. (2000) Szempontok a területi versenyképesség értelmezéséhez. Tér és Társadalom 2-3. 119-128. o.

Síkföi T. (2006) I 25 éves a Pécs-Baranyai Kereskedelmi és Iparkamara (riport). - Dél-Dunántúli Gazdaság. 1. 4-9. o.

Szalai E. (2001) Gazdasági elit és társadalom a magyarországi újkapitalizmusban. Aula Kiadó, Budapest. Számely G. (1996) Vállalkozói érdekképviseletek és kamarák. Doktori disszertáció. BKE, Budapest.

Szigeti P. (2003) Globalizáció és nemzetállami kormányzás. - Lenkei G. (szerk.) Globalizáció. Európai Unió, Gazdaságpolitika. Stratégiai Füzetek 13. MeH Stratégiai Elemzö Központ, Budapest. 51-78. o.

Szirmai V.-Baráth G.-Molnár B.-Szépvölgyi Á. (2003) Globalizáció és Területi fejlödés. Tér és Társadalom. 3. 29-57. 0.

Szirmai V.-A. Gergely A.-Baráth G.-Molnár B.-Szépvölgyi Á. (2002) Verseny és/vagy együttmüködés (város és környéke kapcsolatai). MTA Szociológiai Kutatóintézet - MTA RKK NYUTI KözépDunántúli Kutatócsoport, Budapest-Székesfehérvár.

Szücs I. (2006) 125 éves a Pécs-Baranyai Kereskedelmi és Iparkamara (riport). - Dét-Dunántúli Gazlaság. 1. 4-9. o.

Varga Cs. (2000) A lokalitás esélyej. InCo internetes folyóirat. Elérhetöség: www.inco.hu/inco3/ kozpont/cikk!

Veress J. (2004) A gazdaságpolitika szerepe a modern gazdaságokban. - Veress J. (szerk) Fejezetek a gazdaságpolitikából. Aula Kiadó, Budapest. 13-49. o.

\section{ECONOMIC CHAMBERS AND GLOBALISATION}

\section{PÉTER PÓLA}

Globalisation radically changes local economy. The elimination of the negative impacts of this process with increasing the competitiveness of SMEs embedded into local society are the major tasks of the regional and local institutional system including economic chambers. This paper examines under what conditions and strategies domestic chambers can initiate this process and how local enterprises may increase the competitiveness of local economy. 